\title{
Zones of conflicts and potentialities in the process of becoming an EFL teacher ${ }^{1}$
}

\author{
Zonas de conflitos e potencialidades no \\ processo de se tornar professor de inglês
} COMO LE

Paula Tatianne Carréra Szundy*

Universidade Federal do Rio de Janeiro

Rio de Janeiro - Rio de Janeiro / Brasil

\begin{abstract}
For shifting the focus from completed maturational processes to those that can be potentially developed in the interaction with other(s) and for proposing that while interacting with the varied cultural artifacts people are not only transformed but able to transform the activity, the vygotskian notion of ZPD has indeed become a revolutionary analysis tool in several educational spheres. After drawing the characteristics of ZPD that have contributed to my reflection concerning the construction of knowledge in EFL pre-service teacher education processes, the present paper aims at discussing the zones of potential development revealed in the reports written by three future EFL teachers during English Methodology classes. Framed on the notion of ZPD and on the concepts of ideology, authoritative and persuasive discourse proposed by Bakhtin's circle, the analysis focuses mainly on the conflicts related to the process of becoming an EFL teacher.
\end{abstract}

KEYWORDS: ZPD; critical reflection; ideology; authoritative and persuasive discourse.

RESUMO: Ao mudar o foco de processos maturacionais completos para aqueles que podem ser potencialmente desenvolvidos na interação com outrem e propor que ao interagir com os variados artefatos culturais somos transformados pela atividade e capazes de transformá-la, a noção vygotskiana de ZPD tornou-se uma ferramenta de análise revolucionária na esfera educacional. Após delinear as

\footnotetext{
${ }^{1}$ A version of this paper was presented in the 16th World Congress of Applied Linguistics - Harmony in Diversity: Language, Culture, Society - held at Beijing Foreign Studies University in Beijing, China, in August 2011. I thank FAPERJ Fundação Carlos Chagas Filho de Amparo à Pesquisa do Estado do Rio de Janeiro for the financial support for my participation in this conference.

*ptszundy@uol.com.br; ptszundy@gmail.com
} 
características da ZPD que têm contribuído para minha reflexão sobre a construção do conhecimento no processo de formação pré-serviço de professores de língua inglesa, este artigo pretende discutir as zonas potenciais de desenvolvimento reveladas em relatórios escritos por três futuros professores de inglês como LE durante um curso de Prática de Ensino da Língua Inglesa. Alicerçado na noção de ZPD e nos conceitos de ideologia, discurso autoritário e discurso internamente persuasivo propostos pelo círculo de Bakhtin, a análise foca principalmente nos conflitos vivenciados no processo de se tornar professor de língua inglesa.

PALAVRAS-CHAVE: ZPD; reflexão crítica; ideologia; discurso autoritário e internamente persuasivo.

\section{Introduction}

Based on the vygotskian notion that when we engage in different activities in which we interact with varied instruments, we are not merely influenced by these activities and instruments but also able to transform them in the course of history, Newman and Holzman (1993) assume the zone of proximal development $(\mathrm{ZPD})$ as a revolutionary zone that leads to the unit learning-and-development.

Bearing this conception of ZPD in mind, I propose that the activities in which students are engaged in English Methodology classes to become EFL teachers should somehow revolutionize their views on the teaching-learning processes in order to trigger a potential zone in which learning-anddevelopment are really paired. Revolutions are historically marked by conflicts and these are very likely to happen when future teachers reflect about their activities in the EFL classroom. In this reflective process the theoretical conceptions do not simply represent a set of crystallized ideologies used to analyze actions in the classroom. Most of all, they can become the instruments through which activities are both understood and transformed, leading to transformations in all the participants involved.

Through the analysis of excerpts from reports written by students in an English Methodology class after teaching a thirty-hour course for elementary and high school students, this paper aims at reflecting about the potential learning-and-development that can be grasped of the future teachers' reflection on the experienced EFL classroom practices. In order to do so, the analysis will focus mainly on the discussion concerning the authoritative or persuasive relations (BAKHTIN, 1975) kept with the theoretical constructs that framed the target teaching experience. 
As detailed in other articles (SZUNDY, 2007; 2009; 2010), the target teaching experience was part of a project entitled Didactic Sequences for the construction of reading comprehension in English: elaboration and application carried out in a public university in the state of Acre, in the Brazilian Amazon from 2006 to 2009. This project had as its main foundation the idea that English Methodology classes constitute a privileged space for the development of projects that lead to the theoretical and methodological framed construction of knowledge about the future pedagogical practice so as to engage the studentfuture-teacher in a continuous critical reflection about his/her and about others' actions.

In the focused project the future teachers elaborated didactic sequences ${ }^{2}$ aimed at the development of written comprehension in English and later used these sequences in a thirty-hour extracurricular course offered to elementary and high school students of a state school in Rio Branco, Acre, Brazil. The didactic sequences were elaborated and applied by last year English Language graduate students under my supervision based on proposals postulated by official documents (PCN, OCEM $)^{3}$ and on theories about speech genres and teaching.

After this brief contextualization of the project, the second part of this paper is dedicated to the discussion of the theoretical conceptions that have framed my reflection on the construction of knowledge that takes place in pre-

\footnotetext{
2 Dolz, Noverraz and Schneuwly (2004, p. 97) define a didactic sequence as "a set of school activities systematically organized around an oral or written textual genre". Unlike other didactic materials in which different genres circulate as a pretext to develop reading, writing, listening or oral competences, in a didactic sequence the construction of these competences demands knowledge about the target genre characteristics and, therefore, the skill to manipulate the several capacities (action, discursive and linguistic capacities) required to comprehend and produce texts in a determined genre. It is in this sense that Schneuwly (2004), based on the vygotskian notion of instrument, suggests that speech genres can be considered complex semiotic instruments in the teaching-learning process.

${ }^{3}$ These documents are published by the Ministry of Education with the intention of setting national parameters for the teaching of the several curricular components of basic education (elementary and high school). While the PCN (Parâmetros Curriculares Nacionais [BRASIL, 1998]) establishes curricular parameters for the second cycle of elementary school (from the 5th to the 8th grade), the OCEM (Orientações Curriculares do Ensino Médio [BRASIL, 2006]) aims at orientating the curriculum for the three-year high school in Brazil.
} 
service EFL teachers' reflective processes. This discussion will focus mainly on vygotskian and newvygotskian views of $Z$ PD and on the bakhtinian notions of ideology, authoritative and persuasive discourse. Finally, the third and final part of the paper is oriented towards the analysis of future EFL teachers' report excerpts so as to draw conclusions about the processes of knowledge construction involved in the activity of becoming a teacher.

\section{ZPD as a revolutionary zone: creating spaces for the persuasive discourse}

Based on his critical view about the psychological positions of his epoch in what concerns the complex relationship between learning and development, Vygotsky $(1930,1934)$ proposes a new instrument to analyze this relationship - the zone of proximal development (ZPD). Opposite to the criticized dualist positions, which either saw the learning process as subordinated to the development (maturation) of mental functions or reduced development and learning to habit formation, the ZPD focuses on the activities children can potentially accomplish in collaboration with more experienced partners. By doing so, the vygotskian notion of ZPD underlines the revolutionary role of instruction in developmental processes.

As Vygotsky (1934, p. 188) points out:

In the child's development imitation and instruction play a major role. They bring out the specifically human qualities of the mind and lead the child to new developmental levels. In learning to speak, as in learning school subjects, imitation is indispensable. What the child can do in cooperation today he can do alone tomorrow. Therefore the only good kind of instruction is that which marches ahead of development and leads it; it must be aimed not so much at the ripe as at the ripening functions.

For shifting the focus from the ripened to the ripening processes that can be potentially developed in cooperation, the conception of ZPD has in fact become, as Vygotsky (1930) foretold, a revolutionary method in the analysis of the interrelations between learning-and-development for both psychologists and educators, method which has been largely used in varied contexts to seek comprehension about the processes involved in knowledge construction in the most diverse educational spheres. 
According to Moll (1990), it was Vygotsky's dissatisfaction with traditional psychological tests to measure intelligence quotient that partly led to the development of a different method - the ZPD. Whereas these tests, for measuring only the matured functions, have a static nature, the ZPD allows looking at development prospectively since it focuses on the mental functions that can be potentially developed in interaction with other people in semiotic mediated activities that take place in different social institutions.

When discussing the concept of ZPD, several authors (MOLL [1990]; BERNSTEIN [1993]; DANIELS [1993, 1996, 2001]; NEWMAN; HOLZMAN [1993]; SCHNEUWLY [1994]) underline the focus placed by Vygotsky in the socially semiotic mediated activity, which, as suggested by Newman and Holzman (1993) can be considered revolutionary because at the same time it transforms man, man is also able to transform and, therefore, revolutionize activity. Since our semiotic mediated engagement in several activities in the social world is marked by conflicts, it is reasonable to propose that these activities function as arenas, as stages for ideological battles (BERNSTEIN, 1993), for the learning-and-development processes that start the very moment we are born and last throughout our lifetime.

If the ZPD is figured out as an arena or, quoting Bernstein's words, as stage for ideological battles, the widely quoted vygotskian definition of the ZPD as "the distance between the real level of development, determined through the independent solution of problems, and the potential level of development, determined through the solution of problems under the supervision of an adult or in cooperation with more skilled partners" (VYGOTSKY, 1930, p. 112) as well as the scaffolding metaphor Bruner (1986) proposed based on this definition minimize the idea of conflict inherent to the ZPD. This is so because the scaffolding presupposes that learning leads to development in a linear and vertical way and not spirally, as probably presupposed Vygotsky.

The scaffolding metaphor suggests that in cooperation with more skilled partners the knowledge in the proximal level of development is gradually internalized and ends up becoming part of the real level of development. On the other hand, the spiral image, according to Schneuwly (1994), takes into account that the construction of knowledge in socially semiotic mediated interactions occurs in constant conflict between the two levels of development. Due to this continuous conflict, knowledge construction involves both regression and progression, spiraling several times at the same point as it advances in complexity. 
Vygotsky (1930, p. 74) himself, when discussing the internalization of superior psychological functions, emphasizes that "development does not take place in a circle, but in a spiral, passing by a same point at every new revolution, as it advances to a superior level". It is this spiraled movement metaphor I use to describe the construction of knowledge that takes place in teacher pre-service education projects in which the activities future teachers are engaged may function as arenas where crystallized ideologies about EFL teaching-learning practices are at the same time transmitted, deconstructed and reconstructed in order to reconfigure and revolutionize action in the classroom.

Newman and Holzman (1993) point up that as a sociohistorical unit developed to the study and comprehension of specifically human activities, the ZPD represents the unit learning-and-development and, therefore, the historical psychological unit, the space for the revolutionary activity. The authors support the conception of ZPD as a revolutionary unit under the vygotskian premise that mind is historical, "literally created or produced through the participation in (and the internalization of) socioculturalhistorical forms of activities" (NEWMAN; HOLZMAN, 1993, p. 82). In order to become a revolutionary unit in which learning-leads-to-development, the ZPD cannot be merely understood as the transmission of knowledge from less to more experienced partners, a simplistic comprehension of the ZPD that, according to Moll (1990), has been used to support any kind of instructional practice. Instructional practices in pre-service teacher education just spiral to more complex levels if future teachers are dialectically engaged in activities that transform and are at the same time transformed by them (SZUNDY, 2009).

When Vygotsky $(1930 ; 1934)$ proposed the unit learning-anddevelopment in the ZPD, he emphasized the major role played by the systematic contact with scientific concepts in formal schooling in the development of superior mental processes. Taking into consideration that the reflective process in which future teachers are engaged involve both the construction of scientific concepts and the use of these concepts to frame their practices and reflect about them, the issue concerning the transmission and revoicing of other people's words stands as an important one in teacher preservice and in-service education.

Based on the conception that meaningful dialogues can be established between vygotskian historically founded psychology and the bakhtinian historical philosophy of language (WERTSCH [1990]; FREITAS [1997]; ROJO [2000, 2006]; SZUNDY, [2004, 2006]), I use the bakhtinian concepts 
of ideology, authoritative and persuasive discourse to discuss how the apprehension and comprehension of the scientific concepts used to reflect about the practices experienced in the target pre-service education activity contributed to create zones of conflicts and potentialities that led to learningand-development in the ZPD.

According to Voloshinov (1929) and Bakhtin (1953), the ideological as well as the dialogical nature of language is related to the fact that every single utterance is linked to other utterances in the complex chain of verbal communication and to the proposition that each utterance is directed towards an active other and not a passive listener. This means that the other(s) to whom our utterance is directed always take an active responsive attitude towards it, which can be materialized in the form of a non verbal action, an agreement, disagreement and so forth. The speaker expects this active responsive attitude and his/her utterance is oriented by it.

Although this active responsive attitude is more clearly noticed within the rejoinders of a dialogue, every single utterance, including all the complex genres such as the literary and scientific ones, is oriented toward an addressee, having, consequently, a dialogical character. Like the rejoinders of an everyday dialogue, secondary genres produced by literary, educational, sociopolitical spheres are oriented toward an active response, which can assume various forms: educational influence on the readers, persuasion of them, critical responses, influence on followers and successors, and so on (BAKHTIN, 1953, p. 76)

As both addresser and addressee construct their utterances from a specific situation and are, at the same time, part of a broad sociohistorical context, the structure of the utterance is determined both by the immediate situation and the broader social milieu. Based on the assumption that it is in the process of social interaction that our consciousness is filled with ideological content and constituted as such, Voloshinov (1929) suggests that every apprehension, no matter how simple it may be, is subject to ideological evaluation, reflecting and refracting a reality outside itself.

Since everything ideological possesses meaning: it represents, depicts, or stands for something lying outside itself being, therefore, a sign (VOLOSHINOV, 1929, p. 9), the notion of ideology is a central one to understand the meanings constructed and the evaluations carried out in all our semiotic mediated interactions in the social milieu. As signs and their inherent ideological evaluations are only constituted in interindividual territories, that is, in socially organized activities, each social unit creates its medium of signs 
through which the ideological life of that social group takes shape and is submitted to appreciation.

Each field of ideological creativity reflects and refracts reality in its own way, having a distinct function in the unit of social life. The aggregate of life experiences and the outward expression linked to it is referred to by Voloshinov (1929) as behavioral ideologies, whereas the heterogeneous set of utterances originating from the more complex and structured activities of the artistic, scientific, political and religious spheres are placed within the limits of what the author classifies as established ideological systems, which are considered to be crystallizations of behavioral ideology.

While the established ideological systems of moral, ethics, religion, law, science, etc, have been organized into systems in sociohistorical processes of crystallization, the behavioral ideologies represent the domain of the spontaneous and unsystematic interior and exterior words used to give shape to our conscience and convey meanings in each one of our attitudes and/or gestures. Being historical crystallizations of behavioral ideologies, the conceptions transmitted by established ideological systems are understood, accepted, denied and transformed under the scrutiny of behavioral ideologies. Thus, in an always dialogical movement, the crystallized ideological systems influence and are influenced, transform and are transformed by the behavioral ideologies.

In research that focuses on teacher critical education, it is fundamental that participants understand the complex interplay between behavioral and crystallized ideologies on their practices so that they can comprehend their actions in the classroom and engage in the search for transformation. Such an engagement is made possible in pre or in-service teacher education programs when participants' conceptions about the teaching-learning processes, initially framed by the behavioral ideologies they constructed along their experiences as students, professionals, parents, etc, are understood, analyzed and evaluated through the prism of the crystallized ideological systems transmitted by determined scientific concepts, which reflect and refract specific theoretical affiliations and social expectations concerning the teaching-learning activities.

If, in teacher education programs, the most experienced interlocutor proposes activities that do engage teachers in a continuous reflective process about current pedagogical practices aiming at creating zones for learning-anddevelopment and, ultimately, transforming and reforming both thought and action, the construction of knowledge will take place in an arena, presupposing a conflicting relationship between behavioral and crystallized ideologies, 
everyday and scientific discourse. Taking into consideration that in this knowledge construction process, the didactic practices are framed and interpreted by the scientific discourses revoiced by the most experienced interlocutor, the issues concerning both the transmission and analysis of other people's discourses constitute a central issue in the reflective process.

Frequently, the established ideological systems that constitute the scientific concepts are transmitted through the authoritative discourse in teacher education practices. Since the authoritative word is filled with dogmatism and receives a status of absolute truth in the interior of discourse, it does not open spaces for arguments, refutation, disagreement, transformation and, therefore, for critical reflection. Bakhtin (1975) underlines that the authoritative word - religious, political, moral, the word of science, the father's word, the director's word, etc. - lacks interior persuasion and, therefore, demands of us unconditional recognition and assimilation. Because it is connected to authority, the authoritative word requires distance in relation to itself, what can make the relationship established with it positive or negative, fervent or hostile. Although it is usually surrounded by masses of other words, which interpret, exalt or apply it, the authoritative word establishes with these other words a relation of isolation and inertia, not intermingling with them for the negotiation and construction of new meanings.

To the authoritative word, Bakhtin (1975) opposes the persuasive word. Contrary to that one, the persuasive word does not submit itself to any authority, what makes it many times unknown or even deprived of legality. The zones for potential learning-and-development revealed by the persuasive discourse in teacher education are also qualitatively different since it allows that our words interconnect and intermingle with other people's words. This interconnection is determining in the process of ideological conscience transformation and, consequently, in the search for an independent ideological life.

Given the dialogical and ideological nature of discourse in the bakhtinian philosophy of language, it seems reasonable to suggest that both the authoritative and persuasive words are characterized by conflicting ideological positions. The main difference between them lies in the fact that while the first one, impregnated with dogmatic value, tries to silence these conflicting positions and echo an absolute truth, the second recognizes the variety, the complexity, the conflict and the historical character of social values and, by making them object of appreciation, discussion and negotiation, enables the ideological transformation of participants. 
Taking into consideration the apprehension of other people's discourse that can be observed in the evaluations about an EFL teaching-learning project written by future teachers in final reports as part of the evaluation carried out during an English Methodology course, the next part of this paper focuses on the zones of conflicts and potentialities involved in the reflective process of becoming an EFL teacher.

\section{The reflective process as a zone of learning-and-development}

In order to get their degrees in English or in any other school subject, it is compulsory that Brazilian teachers go through a training period both in elementary and high school, which usually involves observation of other teachers' practices and/or teaching a group of students for a certain period of time, both under the supervision of a teacher educator. The excerpts analyzed in this section were written by three future EFL teachers in the beginning of 2007 after the end of the teaching practices they experienced during the probation period I supervised in English Methodology classes.

In this particular supervision experience, the teaching practices in which a total of eight EFL future teachers were engaged are characterized by two distinct moments. In the first one, the future teachers replaced a teacher who had quit her job in fifth, sixth and seventh elementary school classes due to the legal impossibility for public schools to hire new teachers during electoral periods in Brazil. ${ }^{4}$ Finally, in the second one, the future teachers taught an optional extracurricular course aimed at developing high school students' reading comprehension in English.

Despite the fact that the future teachers were oriented to focus on the construction of reading comprehension in elementary school as well, ${ }^{5}$ the circumstances in which the two practices took place were qualitatively different and so were the appreciations carried out about them. While the teaching

\footnotetext{
${ }^{4}$ It is important to clarify that the public school where the teacher was replaced by senior students belongs to the university and has as one of its purposes the creation of spaces for applying methodological and theoretical issues discussed in the teacher education courses offered by the federal university where the project took place.

5 The orientation to focus on reading comprehension is supported by curricular parameters established for EFL teaching in Brazil, which argue for the focus on reading both on the grounds of the social and academic importance of this skill and of the conditions of EFL teaching in most public schools in Brazil.
} 
practice with elementary school students involved a daily selection and preparation of didactic material, the extracurricular course offered to high school students was part of a teacher education research project that involved the elaboration and application of didactic sequences focusing on a specific genre. The genres modeled in the didactic sequences to develop reading comprehension capacities in this second moment of the target teaching experiences were fables, biographies and news.

The choice to reflect about some excerpts from the final reports in this paper is justified by the fact they depict the future teachers' appreciations about both experiences. Nevertheless, it is important to clear up that as the product of a formative evaluation, these reports dialogue with several other instruments used to engage future teachers in critical reflection about their practices: reflective diaries, reflective discussion sessions, reviews of theoretical and methodological texts, oral seminars, assessments and self assessments.

As pointed up in Szundy (2009, p. 175):

To write the reports, the future teachers received a set of instructions that, in addition to providing information on format (paragraph, space, font, size, number of pages), detailed in topics what to discuss in each part that compounds the report: Introduction, Methodology (Context and Teaching Methodology), Teaching Practice Analysis, Final Remarks and References. In the topic referring to Teaching Practice Analysis it is underlined the necessity of carrying out a theoretically framed analysis of the teaching practices experienced based on reflective diaries, discussions with the supervisor and peers, students' and self assessments. The expectations concerning a critical reflection about their actions in the classroom on the light of conceptions discussed in English Methodology, especially the ones postulated by official documents (PCN and OCEM) and the studies on speech genres and teaching are also specified in the instructions.

As the product of a formative process in which the reflection about teaching practices is supposed to be constructed through the future teacher's comprehension of crystallized ideological systems, the final reports can be considered an important instrument to discuss the potential zones of learningand-development that characterizes the target pre-service teacher education.

The following excerpts reveal that the conflict between the two experienced practices was fundamental for $\mathrm{Mar}^{6} \mathrm{~s}^{6}$ potential learning-and-

${ }^{6}$ The future teachers are identified by the initial letters of their names. 
development, which did seem to have taken place in a stage of ideological battles.

\section{Excerpt $1^{7}-$ Mar's final report}

This time, framing my practice in the sociointeractionist views advocated by the National Curricular Parameters (PCN), the methodology was characterized by being democratic. The teacher (I will refer to the trainees as teachers) was not the only authority in the classroom, the only withholder of knowledge. The student acquired the right to speak, to debate, to share their formal knowledge with their peers and with the teachers themselves. In general, every student had some information about the genre biography and about the people in the selected biographies.

\section{Excerpt 2 - Mar's final report}

In the classroom we practiced the interaction among students and between teachers and students. Student's voice, his/her opinion, guided the approach used in the didactic sequences. This time, it was not the student who waited for the first word, that is, the teacher's word, to know what he/she was supposed to do. It was us, the teachers, who listened to students, took their opinion under consideration to construct or reconstruct ours. The student abandoned his/her stereotype of information deposit. It was not required of them to memorize facts, formulas and rules. $\mathrm{He} / \mathrm{she}$ was free to criticize, suggest, add. From apparently simple practices like these, it is possible to create a citizen conscious of his/her rights and duties, aware of the importance of education, not only a utilitarian importance (to get a better job and salary), but for intellectual development.

The time marker this time used by Mar in both excerpts indicate that her evaluations about the teaching practices were constructed through the confrontation of actions experienced in the two moments detailed above. After confronting her practice in the fifth grade of elementary school with the one experienced with second year high school pupils, Mar evaluates that a dialogue with the sociointeractionist views postulated by National Curricular Parameters (PCN), which was supposed to frame both experiences, was just

\footnotetext{
${ }^{7}$ All the excerpts used in this analysis are extracted from final reports written in Portuguese and were translated into English for this paper.
} 
put into practice in the high school teaching experience. It is this meaningful dialogue with the theoretical framework that seems to be the responsible for the success of the second experience compared to the failure of the first one.

It is possible to note that the mediation of other people's words revoiced in the crystallized ideological systems that support both target teaching experiences allowed Mar to establish a conflicting relationship between the two experiences that, in her evaluation, triggered a change of paradigm in practice. Mar's negative appreciation of the experience in the $5^{\text {th }}$ grade was fundamental to modify her comprehension of the interplay between theory and practice, creating a zone for learning-and-development where transformations were not just possible but desirable. The two excerpts from Mar's final report suggest that the two experiences functioned as stages of ideological battles leading the future teacher to evaluate her actions in the first experience as authoritarian and in the second one as more persuasive. Opposite to the experience with $5^{\text {th }}$ grade pupils, the application of the didactic sequence of the genre biography at high school was characterized by being democratic since the teacher was not the only withholder of knowledge and students' voice guided the approach used in the didactic sequences. The changes constructed through confrontation become desirable under the argument that from apparently simple practices like these, it is possible to create a citizen conscious of his/her rights and duties, aware of the importance of education.

A more persuasive relation with other people's word that allows the theory to penetrate into practice and vice-versa can be noticed in the excerpt below, also from Mar's report.

\section{Excerpt 3 - Mar's final report}

As someone whom I do not remember exactly said once a pedagogical practice that is not framed in a theory, even if it is unconsciously applied, cannot exist. It is there, in need of revelation, or, if it is the case, of acquisition of a formal status. After stating this view, it is necessary to expose and discuss the theories that support this second phase of my training at Colégio de Aplicação. Considerable part of this theory had been introduced in the partial report, however, as it is known, the theories discussed there were not transposed to reality. This "detail" modifies my view on the theories. The view now is that theory can and must penetrate in the classroom space.

Although the theoretical framework that supported the teaching practices both in elementary and high school was the same, Mar admits that 
a pedagogical transposition in which practice was really informed by the ideological systems advocated by the specific theoretical principles that framed the target pre-service teacher education experience just happened with the application of the didactic sequence in high school. In the learning-anddevelopment process Mar went through, the confrontation of traditional crystallized EFL practices that focus on the decontextualized teaching of systemic and lexical components with a contextualized practice that aims at developing the knowledge about genres that circulate in the social milieu was crucial to modify the future teacher's views concerning theory and provoke changes into practice.

Like Mar, other two future teachers - Ra and $\mathrm{Se}$ - who participated in the same pre-service teacher education project, emphasize in their final reports the importance of a theoretical framed reflection about practice so as to change their actions in the classroom.

\section{Excerpt 4 - Ra's final report}

In the perspective of associating the methodology of English for Specific Purpose (ESP) to the approach of teaching reading comprehension through the conception of textual genre, according to the orientation of the National Curricular Parameters (levels of knowledge), the production of didactic material for the classes, instead of adopting a didactic book - became a considerably relevant exercise since it allowed the real and effective comprehension of the gears that support the activities proposed, making it possible to cover almost all the communicative competences in English. ${ }^{8}$ This demonstrated the viability of activities based on these constructs allowing at the same time the adaptation of the activities to the specific demand of each context.

\section{Excerpt 5 - Se's final report}

There were moments in which I noticed a discrepancy between my practice and the theory that guides it. Then I told my friends and myself that we got that right but we need to change this. There lies

\footnotetext{
${ }^{8}$ The notion of communicative competence proposed by Ra does not refer to the traditional skills involved in language learning (reading, writing, listening and speaking), whereas it is related to the four competences involved in language learning postulated by Savignon (1983): linguistic, sociolinguistic, discursive and strategic competences.
} 
the importance of reflecting about our own practices. Only through reflection we can avoid that mistaken teaching practices become crystallized in us and intermingle with the theory we advocate when they diverge completely from it.

I believe we accomplished our main purpose, that is, to approach the reading comprehension in English exploring students' world, systemic and textual knowledge so as to increase their future knowledge always in the perspective that knowledge is a social construct. In high school our practice was enriched by a more systematic work with the notion of textual genres.

In addition to depicting the future teachers' evaluations on how a systematic reflection about the teaching practice supported by specific theoretical and methodological conceptions is fundamental to planning, understanding and transforming actions, the five excerpts above also reveal that Mar, Ra and Se were able to establish persuasive relations with other people's discourse in the sense that the several voices that constitute the theoretical framework intermingled in the process of constructing knowledge about the future practice. However, it is also possible to observe that while the confrontation of a teaching experience evaluated as negative with another perceived as positive constituted the material that led to Mar's learning-anddevelopment, Ra's and Se's potential learning-and-development is characterized by a complementary relationship between the practices experienced in elementary and high school.

Opposite to Mar, Ra and Se do not seem to have experienced an initial rejection to the theoretical frameworks that supported both practices. On the contrary, their reflections indicate that they agreed from the beginning with the ideological principle that the combination of ESP principles with the notion of textual genres can be viably combined in the development of activities to construct reading comprehension in EFL teaching practices $(\mathrm{Ra})$ since these theoretical principles share the idea that knowledge is a social construct $(\mathrm{Se})$. Instead of leading to a complete rupture, as observed in Mar's reflection, the initial theoretical affiliation and engagement into a practice that sought to construct reading comprehension relating the text to the context and working with the three levels of knowledge proposed by the PCN - world, systemic and textual knowledge - made Ra's and Se's practices with reading in elementary school to spiral in complexity in high school where the didactic modeling of speech genres allowed an effective comprehension of the gears that 
support the activities proposed $(\mathrm{Ra})$ and the enrichment of practice with a more systematic work with the notion of speech genres.

Among all the crystallized ideological concepts that contributed to frame Mar's, Ra's and Se's appreciations about the experienced practices and create zones for their potential learning-and-development in the activity of becoming EFL teachers, it can be noted in the excerpts below that the concept of ZPD itself was crucial in their evaluation concerning both the progression of knowledge construction and the role of interaction.

\section{Excerpt 6 - Mar's final report}

Before beginning the issue of evaluation, I feel it is necessary to report a problem detected in the didactic sequence. I refer to the progression of contents. There was a moment in which new knowledge concerning the structural properties of biographies was not added. As a result, the construction of these properties in the biography got repetitive and students noticed it. I believe there was a small flaw relating to the position of certain items in the sequence. They could have been better distributed so as to constantly offer a new peculiarity, a new detail about the genre.

\section{Excerpt 7 - Ra's final report}

The notion of Vygotsky's knowledge construction and the definition of ZPD helped to understand the phases involved in the student knowledge construction process. As classes followed and activities were recaptured, students gradually became independent to carry out determined activities, which had been observed in other contexts. Underestimate students' comprehension skill was, certainly, the greatest flaw. The encouragement and valorization of students' strategic competence reduced the level of anxiety and increased selfconfidence. Without the use of dictionary and translation imposition, they could make reading more efficient and autonomous.

\section{Excerpt 8 - Se's final report}

It is precisely in the Zone of Proximal Development that teaching professionals may act, inviting their pupils to participate actively in the teaching-learning process, expressing their ideas and sharing their difficulties with peers and teachers so as to make learning a reciprocal process in which teacher and student learn and feel co-authors in the knowledge construction process. 
Unlike Ra and Se, it can be noticed that Mar does not explicitly name the notion of ZPD to establish appreciations about the phases involved in the student knowledge construction process $(\mathrm{Ra})$ or to construct considerations on how professionals may act in the teaching-learning process (Se). Instead, Mar seems to be worried in pointing out problems she perceived in the didactic sequence in what concerns the (lack of) knowledge progression. Nevertheless, in spite of not naming it, it is the concept of ZPD as a zone aimed at providing situations in which knowledge should progress in complexity that supports her critical evaluation that the sequence of activities proposed did not account for an interesting progression of the structural properties of biographies, making knowledge construction be perceived by students as rather repetitive.

The idea of progression can also be noticed in Ra's transposition of the ZPD notion to seek comprehension about the knowledge construction process she experienced. Through the appreciation established by this future teacher, it is possible to suggest that progression took place through retaking. Therefore, recapturing is posed as a fundamental process that led to students' gradual independence and fostered self-confidence, allowing knowledge in the proximal level of development to be internalized in collaborative activity.

Collaboration also represents an important aspect of the ZPD in Se's evaluation, who underlines the fact that it is precisely in the Zone of Proximal Development that teaching professionals may act, inviting their pupils to participate actively in the teaching-learning process. The fact of establishing collaboration and participation as key elements of the ZPD leads Se to the conclusion that learning is a reciprocal process in which teacher and student learn and feel co-authors in the knowledge construction process.

The capacity to transpose the crystallized concept of ZPD to interpret concretely experienced teaching-learning practices constitute a revelation of the three future teachers learning-and-development processes and an indication that the transmission and apprehension of other people's discourse represents an important issue in teacher education programs. It is specifically on this issue I concentrate in the concluding remarks of this paper.

\section{Concluding Remarks}

The brief analysis of the eight excerpts from Mar's, Ra's and Se's final reports intended to reflect on the zones of learning-and-development that characterizes the process of becoming an EFL teacher. In this complex process, the transmission and apprehension of other people's discourses play a 
fundamental role since all the activities involved in the teaching-learning process are evaluated and eventually transformed through participants' comprehension of determined historically crystallized scientific concepts and their capacity to transpose these concepts to concrete teaching-learning situations involving both the elaboration and implementation of didactic sequences to develop reading comprehension in English as a foreign language.

Through the evaluations carried out by the three future teachers in their final reports, it is possible to outline some considerations about their responsive attitude towards the scientific concepts that framed the teaching practices experienced. Based on the bakhtinian presuppose that every utterance reflects and refracts reality, it is possible to suggest that the appreciations delineated by Mar, Ra and Se in their reports both reflect their responsive attitude towards other people's words and refract broader social expectations concerning EFL teaching-learning process.

The fact that the three future teachers approve practices in which students contributions and voices are valued, interaction play an essential role and teachers and pupils are co-authors in knowledge construction processes while historically crystallized practices in which teachers are the only withholder of knowledge and the EFL instruction is focused on the teaching of decontextualized grammar with no connections established between language and its functions in the real world are condemned, reflects the teachers' responsive attitude towards theoretically informed practices and refracts broader social expectations concerning the roles and actions involved in teaching languages, expectations systematically organized into crystallized ideological principles revoiced in several academic genres and in the Brazilian national curricular parameters.

Finally, I conclude the present reflection using once more the spiral shape as a metaphor to portray the transmission and apprehension of other people's discourse involved in the process of becoming an EFL teacher. This complex process involves reconsideration and deconstruction of certain paradigms so as to understand and transpose to practice current crystallized ideologies in order to reconstruct actions according to certain social expectations. Thus, as it happens in the movement of a spiral, reflecting about practice involves constant reconsideration and reconstruction of other people's discourse in order to spiral to a more complex understanding of one's own action; and in this learning-and-development continuous process both actions and participants are transformed. 


\section{References}

BAKHTIN, M. M. (1953). The problem of speech genres. In: BAKHTIN, M. M. Speech genres and other late essays. Translated by Vern W. McGee. Texas: University of Texas Press, 1986. p. 60-98.

BAKHTIN, M. V. (1975). Questóes de Literatura e de Estética: a teoria do romance. São Paulo: Editora da UNESP, 1998.

BERNSTEIN, B. Prefácio. In: DANIELS, Harry (Org.). Vygotsky em foco: pressupostos e desdobramentos. Campinas: Papirus Editora, 1993.

BRASIL, SEF/MEC. Parâmetros Curriculares Nacionais - $3^{\circ}$ e $4^{\circ}$ ciclos do Ensino Fundamental - Lingua Portuguesa. Brasília, DF: SEF/MEC, 1998.

BRASIL, SEB/MEC. Orientaçôes Curriculares para o Ensino Médio: linguagens, códigos e suas tecnologias. Brasília, DF: SEB/MEC, 2006.

BRUNER, J. S. Actual Minds, Possible Worlds. Cambridge, MA: Harvard University Press, 1986.

DANIELS, H. Apresentação. In: DANIELS, Harry (Org.). Vygotsky em foco: pressupostos e desdobramentos. Campinas: Papirus Editora, 1993.

DANIELS, H. (1996). Uma Introdução a Vygotsky. Tradução de Marcos Bagno. São Paulo: Ediçōes Loyola, 2002.

DANIELS, H. (2001). Vygotsky e a Pedagogia. Tradução de Milton Camargo Mota. São Paulo: Edições Loyola, 2003.

FREITAS, M. T. A. Bakhtin e Vygotsky: um encontro possível. In: BRAIT, B. (Org.) Bakhtin, Dialogismo e Construção do Sentido. São Paulo: Editora da Unicamp, 1997. p. 311-330.

DOLZ, J.; SCHNEUWLY, B.; NOVERRAZ, M. Seqüências didáticas para o oral e a escrita: apresentação de um procedimento. In: SCHNEUWLY, B.; DOLZ, J. et al. Gêneros orais e escritos na escola. Campinas, SP: Mercado de Letras, 2004. p. 95-128.

MOLL, L. C (1990). Vygotsky e a educação: implicações pedagógicas da psicologia sócio-histórica. Tradução de Fani A. Tesseler. Porto Alegre: Artes Médicas, 1996. NEWMAN, F.; HOLZMAN, L. (1993). Lev Vygotsky: cientista revolucionário. São Paulo: Edições Loyola, 2002.

ROJO, R. H. R. Interação em sala de aula e gêneros escolares do discurso: um enfoque enunciativo. In: CONGRESSO DA ABRALIN, 2. Anais... Florianópolis: UFSC/ABRALIN, 2000. CD-ROM. 
ROJO, R. H. R. Fazer lingüística aplicada em perspectiva sócio-histórica: privação sofrida e leveza de pensamento. In: MOITA LOPES, L. P. (Org.) Por uma lingüistica aplicada indisciplinar. São Paulo: Parábola Editorial, 2006. p. 253-276.

SCHNEUWLY, B.; DOLZ. J. Gêneros e progressão em expressão oral e escrita - elementos para reflexões sobre uma experiência suíça (francófona). In: ROJO, R.; CORDEIRO, G. S. (Org. e tradutoras) Gêneros Orais e Escritos na Escola. São Paulo: Mercado de Letras, 2004. p. 41-70.

SAVIGNON, S. J. (1983). Communicative Competence. Reading, MA: AddisonWesley Publishing Company, 1983.

SCHNEUWLY, B. Contradiction and development: Vygotsky and paedology. European Journal of Psychology of Education, v. 9, n. 4, p. 281-291, 1994.

SZUNDY, P. T. C. Gêneros do discurso no processo de ensino-aprendizagem de LE: a construção do conhecimento por meio do discurso internamente persuasivo. The ESPecialist, v. 25, n. 2, p. 153-175, 2004.

SZUNDY, P. T. C. Scientific and spontaneous concepts, primary and secondary genres, behavioral and crystallized ideologies: possible interrelations and educational implications. The ESPecialist, v. 27, n. 2, p. 213-233, 2006.

SZUNDY, P. T. C. Seqüências didáticas para desenvolvimento da habilidade de leitura em língua inglesa: elaboração e aplicação. Signum Estudos da Linguagem, v. 10, n. 2, p. 43-263, 2007.

SZUNDY, P. T. C. Construção do conhecimento sobre a futura prática pedagógica: reflexôes de alunos-professores sobre um projeto de prática de ensino da língua inglesa. In: TELLES, J. A. (Org.). Formação inicial e continuada de professores de línguas: dimensões e ações na pesquisa e na prática. Campinas, SP: Pontes, 2009. p. 167-181.

SZUNDY, P. T. C. Modelização didática de gêneros e a formação do futuro professor de língua inglesa: implicações no processo de construção do conhecimento. Revista Letras, v. 20, n. 40, p. 217-237, 2010.

VOLOSHINOV, V. N. (1929). Marxism and the philosophy of language. Translated by Ladislav Matejka and I. R. Titunik. Cambridge, MA: Harvard University Press, 1973.

VYGOTSKY, L. S. (1930). Mind in society: the development of higher psychological processes. Edited by Michael Cole, Vera John-Steiner, Sylvia Scribner, Ellen Souberman. Cambridge, MA: Harvard University Press, 1978. VYGOTSKY, L. S. (1934). Thought and language. Translated by Alex Kozulin. Cambridge, MA: The MIT Press, 1986. 
WERTSCH, J. V. A voz da racionalidade em uma abordagem sociocultural da mente. In: MOLL, L. C. (Org.). Vygotsky e a educação: implicaçōes pedagógicas da psicologia sócio-histórica. Tradução de Fani A. Tesseler. Porto Alegre: Artes Médicas, 1990/1996, p. 107-121.

Recebido em 13/2/2012. Aprovado em 7/4/2012. 